\title{
ISSUES OF PREVENTING AND FIGHTING FROM THE DRUG ADDICTION AMONG YOUNG PEOPLE
}

\author{
Zokhidjon Mingodilovich Khayitmatov \\ Senior teacher at the department "Theory of civil society" of Andizhan State University, Andizhan, \\ Republic of Uzbekistan
}

Article DOI: https://doi.org/10.36713/epra2268

\begin{abstract}
The article analyzes the ways in which the drug spread and its adverse effects, which are of concern and threat to the international community, are based on scientific examples. In addition, the article also describes the fate of young people who become victims of these drugs, especially young people.

KEY WORDS: Drug addiction, drug addiction, heroin, opium, Middle East region, Central Asia, South, West Asia, global, extremism, terrorism, arms trafficking, human trafficking.
\end{abstract}

\section{INTRODUCTION}

In the $21^{\text {st }}$ century, the world has brought many unexpected and unexpected challenges to mankind. In some countries, science and technology have been making progress in science and technology, and young people in those countries have been able to achieve much technical and technological advancement. Growing up has created a number of problems. Consequently, there is an increasing number of diseases in these regions that are becoming an unrestrained global threat, such as extremism, terrorism, arms trafficking, human trafficking, drug addiction, and crime and evil. It is a pity that young people between the ages of 14 and 30 are the main victims of these diseases, and the world has been vigilant with regard to the education and development of young people. President Shavkat Mirziyoyev made the following remarks at the $72^{\text {nd }}$ session of the UN General Assembly on September 19, urging people around the world to draw attention to the protection of youth from the global and global threats of terrorism.

"The growing threat of terrorism in the world, especially in recent years, is an indication that the mainly violent methods of fighting against them are not justified", he said. In this regard, it is often confined not only to the underlying causes of threats, but to their consequences. I think ignorance and intolerance are at the root of international terrorism and extremism. In this regard, the most important task is to educate and educate the people, especially the youth, on the basis of education.

Most crimes related to extremist activity and violence are committed by young people under the age of 30. The youth of today's world is the largest generation in the history of humanity because they number 2 billion. The well-being of our planet tomorrow depends on the kind of person our children become.

Our main task is to create the necessary conditions for young people to realize their potential and to prevent the spread of the "virus" of the idea of violence.

We believe that it is necessary to develop multilateral cooperation for social support of young generation, protection of its rights and interests. In this regard, Uzbekistan proposes to develop a general international legal document - the UN Convention on the Rights of the Youth, aimed at the formation and implementation of youth policy in the rapidly developing environment of globalization and information and communication technologies. In our view, the signatories should undertake a strong commitment to make this area 


\section{EPRA International Journal of Research and Development (IJRD)}

one of the most important and vital priorities of their social policy" [1, p.244].

\section{METHODS}

The proposal from the UN tribunal to prevent young people under the age of 30 , who are victims of extremism and terrorism and drug addiction, to the nearly two billion people of the world, to keep them out of their control and to protect their rights and interests politically and socially. Hundreds of thousands of young people are victims of drug addiction, especially as a result of this addiction, aggression and untreated diseases that spread to the world.

Today's plague is becoming ever more popular among young people. Increasing the role of international organizations in combating the negative effects of this malady has become a topical issue. In particular, the resolution of the General Assembly of the United Nations on December 7, 1987 (No.42 / 112). The International Day Against Drug Abuse and Illicit Trafficking is celebrated each year on June 26. The annual event is named separately, and the slogan of the 2019 event is "Listen First".

According to the United Nations Office on Crime and Drug Control, the number of drug addicts in 2015 has exceeded 300 million in recent years. Consequently, the highest consumption of drugs is cannabis today. It was the first time a century ago, the cooperation in the fight against drugs began. In February 1909, representatives of 13 countries gathered in Shanghai to combat drug trafficking in Asia. Then a commission was established in Shanghai. Despite the measures taken, the UN General Assembly recognized that drug trafficking remains a problem in the world [2]. This problem is still considered a serious threat. According to the World Statistics, $1.3 \%$ of deaths between 15 and 64 are caused by addiction. Drug addiction is one of the 211,000 deaths a year. The average age of drug addicts in Europe is 35 years. According to experts, 1.6 million people will be infected by the drug. 7.2 million people are infected with hepatitis C. 1.2 million people suffer from hepatitis B.

\section{RESULTS AND DISCUSSIONS}

By the early $20^{\text {th }}$ century, the plague that plagued humanity and the plague of humanity had spread to many parts of the world as a disease. Unfortunately, these drugs are grown and processed in neighboring Afghanistan, with the necessary chemicals being smuggled into the territory of our republic in various ways, smuggling through neighboring Kyrgyzstan and Tajikistan. As a result, drug addiction is growing in the population, especially among the youth. According to the Ministry of Internal Affairs of the Republic of Uzbekistan, Tashkent city police, 989 criminal cases have been initiated by the end of 2018, and more than 50 kilograms of various drugs were seized as evidence. In particular, in 2018, 121 drugrelated cases were reported [3]. In our country, preventive and operative measures are being taken to prevent the drug addiction of young people and to eliminate them, especially the penetration and spread of drugs and synthetic drugs in the country.

Thus, in 2018 the number of crimes related to illicit drug trafficking decreased by $12 \%$ and amounted to 4,779. The number of drugs seized by law enforcement in 2018 declined by 41.2 percent to 1.17 tonnes. $20.6 \mathrm{~kg}$ of heroin, $254.7 \mathrm{~kg}$ of opium, $600.8 \mathrm{~kg}$ of marijuana, $61.4 \mathrm{~kg}$ of hashish, $227 \mathrm{~kg}$ of poppy, 165.7 grams of new psychoactive substances and 7,551 grams of tramadol. In 2018, the courts have dealt with a total of 2,876 criminal cases related to illicit drug trafficking, with 3,691 individuals taking appropriate penalties. Unfortunately, 208 of these criminals were women. 904 cases of poppy and cannabis planting have been identified during a large-scale "Black Medicines 2018" on a total of 2,664 square meters. In addition, in 449 cases 7.5 thousand sq. M. wild-growing marijuana plants have been identified and destroyed in the area [4].

In 2018, the number of drug addicts in Uzbekistan was 6,142 as a result of drug addiction. "The Central Asian region is a cross-border point for drug trafficking. In this regard, health and wellbeing are also shown to be sustainable for the UN's sustainable development goals, and this requires first of all the drug addiction". The UN's development agenda until 2030 is based on the slogan "No one should be left behind" [5].

As a result of large-scale preventive and operational activities in cooperation with the Ministry of Internal Affairs and other law enforcement agencies, in 2019, 4611 drug-related crimes were detected and about 1 ton of drugs (131 $\mathrm{kg}$ of heroin and opium, $49 \mathrm{~kg}$ of hashish, $693 \mathrm{~kg}$ of marijuana, $62 \mathrm{~kg}$ of poppy and $19 \mathrm{~kg}$ of psychotropic substances, synthetic and narcotic drugs. In particular, on March 6 and 16, 2019, nine organized groups (one of them citizens of Tajikistan) were arrested in the Samarkand region for smuggling and selling large quantities of drugs from the Republic of Tajikistan. and $25.7 \mathrm{~kg}$ of opium were seized as evidence. 
In Tashkent on February 3-21, nine members of the criminal group involved in smuggling of narcotic drugs from the Republic of Kazakhstan to the territory of the Republic were detained, 148,550 units of drugs "Tramadol" and "Phenazepam" psychotropic substances [6]. Currently, there is a number of official meetings between the CIS and Central Asian states on joint efforts to combat illicit drug and psychotropic substances in the protection of young people from the grave consequences of the drug's plague. Therefore, the Agreement between the Russian Federation, Azerbaijan, Kazakhstan, Uzbekistan, Kyrgyzstan, Tajikistan and Turkmenistan on the establishment of the Central Asian Regional Information Coordination Center for Combating the Illegal Trafficking of Narcotic Drugs, Psychotropic Substances and their Precursors (Astana, 200624 July) on ratification, "On drugs and psychotropic substances", "On citizens' health", "Food products" Adoption of the Law on Quality and Safety, "On the Treatment of Chronic Alcohol, Drug or Toxic Patients" is the most encouraging step towards building a healthy future [7].

\section{CONCLUSION}

In conclusion, Uzbekistan, where more than $50 \%$ of the population is under 30 years of age, has been making significant efforts to nurture and bring up a fully developed generation. The issue of youth has been raised to the level of public policy. However, the efforts of a group of criminal gangs that put their interests ahead of the development and prosperity of the country are trying to spur drug abuse and violence among the young people. Such a letter - the movement will have a serious impact on the development and future of the state and society. Today, we aim to fight against ideas, ideas against ideas, and enlightenment against ignorance. We make a grave mistake, that is, irreparable error, if we are not vigilant in the face of the destructive ideas of criminal gangs, who are constantly vigilant and alert for their youth to be worthy of their ancestors.

\section{REFERENCES}

1. Mirziyoev Sh. The consent of our people is the highest value given to our work.Volume 2Tashkent: Uzbekistan, 2018.-p.244.

2. Tulyaganov Sh. June 26 is the International Day Against Drug Abuse and Drug Trafficking. //https://kun.uz/17827148?q=\%2F17827148

3. Nurullaeva Sh. Youth - against drugs addiction! // http://darakchi.uz/uz/66504
1. 4.Abduraimova N. Last year, Uzbekistan seized 1.17 tonnes of drugs. //https://hordiq.uz/2019/06/25/uzbekistondautgan-yilda-117-tonna-narkotik-moddalarmusodara-qilindil

4. Ashita Mittal. International Narcotics Day: Drug Facts and Figures //http://www.ncdc.uz/uz/presstsentr/mezhdunarodnye-vstrechi-imeropriyatiya/2018/07/736/

5. In 4611 cases of drugs, about 1 ton was confiscated //https://kun.uz/news/2020/02/06/giyohvandlikvositalari-bilan-bogliq-4611ta-holatda-1tonnaga-yaqin-moddalar-musodara-etilgan

6. Goyipov O. Drug addiction plague. //http://diyonat.uz/index.php/ma-olalar/645gijokhvandlik-asr-vabosi 